death had dictated her doubts on the authenticity of the Vinland map.

She was educated at the North London Collegiate School for Girls and, after taking a degree in chemistry in the University of London, spent several years as a science mistress at Burton-on-Trent. Seeking to improve her teaching qualifications, she went up to Oxford to take the Diploma in Education. There she came under the influence of A. J. Herbertson and was swept into his activities in developing the 'new geography', both in the Oxford department and through his text-books in the schools. She stayed on as his assistant, working on the preparation of the famous Oxford wall maps and, on a vacation course, met J. F. Unstead. The series of textbooks she produced with him had a great influence in the schools.

It was, however, her appointment as lecturer at Birkbeck College under Unstead in 1921 which marked the turning-point in her career. She turned her attention to historical geography and published Tudor Geography and Late Tudor and Early Stuart Geography. They established firmly her academic standing so that, when Unstead retired in 1930, she succeeded him as professor of geography and so remained until she retired in 1944. In those years she became not only the acknowledged expert in the maps and literature of tho Tudor and Stuart periods, but also in the instruments of navigation and the work of contemporary explorers. A series of papers in the Mariner's Mirror and the Journal of the Institute of Navigation culminated in her The Haven-finding Art.

But Prof. Taylor was far from being immersed in the past. She threw herself with enthusiasm into physical planning and became a member of Lord Reith's Consultative Panel in 1941, with the inauguration of the Ministry of Town and Country Planning. She is still remembered by planners as the originator of the 'sieve method'-by eliminating or sieving out areas unsuitable for development for one reason or another there remains a positive field within which to work.

A woman of strong personality and trenchant language verging on abuse, there were occasions when it was easier to be on the other side, for she never minded opponents who hit back. But her positive opinions were based on wide knowledge, and the bubble reputations she delighted to prick usually deserved this treatment. She retained her maiden name throughout her life and, though proud of her two sons, she kept her domestic life entirely separate from her academic. Shortly after her retirement her work was recognized by the award of the Victoria Medal of the Royal Geographical Society, and her students, subscribing in large numbers, endowed a named lecture at the Society in her honour. L. Dudley Stamp

\section{Fritz Zernike}

Prof. Fritz Zernike, who died on March 10 in Groningen, Holland, was born in Amsterdam on July 16, 1888. His father was headmaster of an elementary school and his mother had been a schoolteacher. Their six children formed a lively and intellectually stimulating family. At nineteen, as a student of chemistry at Amsterdam, Zernike was awarded a gold medal by the University of Groningen for an essay on a probabilistic treatment of a certain parlour game. In 1912 he received another prize for work on critical opalescence, and in $1914 \mathrm{his}$ collaboration with L. S. Ornstein resulted in the OrnsteinZernike formula, which plays a central part in the theoretical and experimental investigation of the critical point. In 1915 he obtained his doctor's degree with a thesis, L'opalescence critique, théorie et expériments, in which the formula for extinction by scattering near the critical point was derived by means of the grand canonical ensemble. The experiments he reported agreed with the theoretical result and made possible a determination of Avogadro's constant to within a few per cent.
In the meantime, Zernike had become an assistant to J. C. Kapteyn, the astronomer at Groningen, but soon afterwards he was appointed a reader in theoretical physics at the same university, and then, in 1920, a full professor. $\mathrm{He}$ continued the investigation of the pair correlation function $g(\mathrm{r})$ occurring in the OrnsteinZernike formula, and in collaboration with J. A. Prins applied it to X-ray diffraction in liquids. His interest in statistical physies also led to a study of the influence of Brownian motion on the measurement of small currents and, characteristically, he put his thcoretical understanding to practical use by construeting an improved galvanometer.

Zernike's unique combination of mathematical insight and technical ability proved very fruitful when he directed his attention to optics. Rather than obscuring a problem by laborious calculations, he would reduce it to its simplest mathematical elements which would then serve as stepping-stones for his physical intuition and inventiveness. For example, he showed that the difference between the rival theories of Abbé and Rayleigh concerning the microscopic image formation is nothing but a difference in order of integration. The discovery of phase contrast microscopy in 1932 was virtually a natural consequence of this method; in fact, when Zernike explained the principle it was hard to understand why it had not been discovered earlier. Perhaps that makes understandable why, when he offered his invention to Zeiss, the leading optical industry in those days, the haughty reply was: "Wenn es interessant wäre, so hätten wir es schon längst selbst erfunden". Yet some development work was carried out at Zeiss, and the first motion picture of cell meiosis was made. Phase microscopy did not become widely known, however, until Arthur T. Bryce, of the U.S. Army, arrived in Jena in 1945 and immediately realized its importance.

Meanwhile, Zernike turned his attention to another problem in microscopy-What is the influence of small aberrations on the diffraction pattern in the image plane? As an appropriate mathematical tool he introduced "circle polynomials" and, in collaboration with B. R. A. Nijboer, the work was successfully completed in 1942 . In the same years Zernike developed the concept of "degree of coherence", constructed a useful poor man's ultracentrifuge using the motor of a vacuum cleaner, published a quantitative treatment of the Senftleben effect with C. van Lier, gave an approximate treatment of the phase transition in binary alloys, and worked on the technical problem of how to manufacture the phase rings needed for his microscope.

Relativity theory and quantum mechanics were of less interest to Zernike, presumably because they lacked the intimate connexion with technical applications which made classical physics so fascinating to him. He was not easily persuaded to publish his results and ideas, but when he wrote an article it was earefully planned and lucidly written. His public addresses were full of brilliant ideas and he had a masterful way of utilizing a simple analogy to throw new light on an old problem. His contacts with other scientists were rather limited, partly because he was so much absorbed in his own research, and partly because re felt ill at ease with people who could not appreciate that the short, often witty, and sometimes caustic way in which re expressed his opinion was just another aspect of his search for unadulterated truth. Unfortunately, this gentleness made him rather defenceless in the turmoil of university politics. His friends, however, will not forget row his great knowledge, widespread interest, and penetrating and refreshingly unprejudiced views made his conversation an intellectual enjoyment.

Official recognition came late, first in the form of the Rumford Medal in 1952, and in the next year the Nobel Prize for his invention of the phase contrast microscope. Zernike was a Foreign Member of the Royal Society of London.
N. G. VAN KAMPEN 